\title{
Overexpression of MdZAT5, an C2H2-Type Zinc Finger Protein, Regulates Anthocyanin Accumulation and Salt Stress Response in Apple Calli and Arabidopsis
}

\author{
Da-Ru Wang ${ }^{1}{ }^{(D}$, Kuo Yang ${ }^{1}$, Xun Wang ${ }^{1}{ }^{\mathbb{D}}$, Xiao-Lu Lin ${ }^{2}$, Lin Rui ${ }^{1}$, Hao-Feng Liu ${ }^{1}$, Dan-Dan Liu ${ }^{3, *}$ \\ and Chun-Xiang You ${ }^{1, *}$
}

1 National Key Laboratory of Crop Biology, National Research Center for Apple Engineering and Technology, College of Horticulture Science and Engineering, Shandong Agricultural University, Taian 271018, China; 15953327292@163.com (D.-R.W.); kuokuoy@163.com (K.Y.); wx20145015@126.com (X.W.); smileboy2021@163.com (L.R.); haofengliu3@163.com (H.-F.L.)

2 College of Plant Protection, Shandong Agricultural University, Taian 271018, China; 15621322802@163.com

3 College of Agriculture, Yunnan University, Kunming 650091, China

* Correspondence: liudandan@ynu.edu.cn (D.-D.L.); youchunxiang@sdau.edu.cn (C.-X.Y.)

Citation: Wang, D.-R.; Yang, K.; Wang, X.; Lin, X.-L.; Rui, L.; Liu, H.-F.; Liu, D.-D.; You, C.-X. Overexpression of MdZAT5, an C2H2-Type Zinc Finger Protein, Regulates Anthocyanin Accumulation and Salt Stress Response in Apple Calli and Arabidopsis. Int. J. Mol. Sci. 2022, 23, 1897. https://doi.org/10.3390/ ijms23031897

Academic Editor: Massimiliano Tattini

Received: 3 January 2022

Accepted: 31 January 2022

Published: 8 February 2022

Publisher's Note: MDPI stays neutral with regard to jurisdictional claims in published maps and institutional affiliations.

Copyright: (C) 2022 by the authors. Licensee MDPI, Basel, Switzerland. This article is an open access article distributed under the terms and conditions of the Creative Commons Attribution (CC BY) license (https:// creativecommons.org/licenses/by/ $4.0 /)$.

\begin{abstract}
Zinc finger proteins are widely involved and play an important role in plant growth and abiotic stress. In this research, MdZAT5, a gene encoding C2H2-type zinc finger protein, was cloned and investigated. The MdZAT5 was highly expressed in flower tissues by qRT-PCR analyses and GUS staining. Promoter analysis showed that MdZAT5 contained multiple response elements, and the expression levels of $M d Z A T 5$ were induced by various abiotic stress treatments. Overexpression of MdZAT5 in apple calli positively regulated anthocyanin accumulation by activating the expressions of anthocyanin biosynthesis-related genes. Overexpression of MdZAT5 in Arabidopsis also enhanced the accumulation of anthocyanin. In addition, MdZAT5 increased the sensitivity to salt stress in apple calli. Ectopic expression of MdZAT5 in Arabidopsis reduced the expression of salt-stress-related genes (AtNHX1 and AtABI1) and improved the sensitivity to salt stress. In conclusion, these results suggest that MdZAT5 plays a positive regulatory role in anthocyanin accumulation and negatively regulates salt resistance.
\end{abstract}

Keywords: apple; MdZAT5; anthocyanin; salt tolerance

\section{Introduction}

Among the numerous external natural environmental factors, light (one of the most important) affects the entire plant life cycle [1-3]. Light is an essential factor in anthocyanin synthesis [4]. Previous studies have shown that the longer the light exposure and the greater the light intensity, the more conducive to anthocyanin formation [5,6]. Additionally, salt is one of the most important environmental stresses, which limits the growth and development of plants and poses a serious threat to global agriculture $[7,8]$. Salt stress significantly inhibits the growth of apple plants, mainly manifesting in slow growth, leaf wilting, and other symptoms, which even leads to plant death in serious cases [9]. Salt tolerance varies amongst different apple varieties. For example, Red fruit Begonia is affected by salt stress at $0.5 \mathrm{mg} / \mathrm{g} \mathrm{NaCl}$, and Mulus zhumei and Midget Crabapple appear to be affected by salt stress at $5.5 \mathrm{mg} / \mathrm{g} \mathrm{NaCl}$ [10]. In order to adapt to complex and changing environmental factors, complex regulatory mechanisms have gradually evolved in plants [11-13]. At present, many transcription factors have been found to regulate anthocyanin accumulation and respond to salt stress, such as MYB, bHLH, WRKY, ZFP, DREB/CBF, NAC, and AP2/ERF [14-21].

Zinc finger proteins are among the most widely distributed proteins in eukaryotes [22,23]. The Cys2/His2 (C2H2)-type zinc finger proteins, also known as TFIIIA zinc 
finger protein, are the most common protein in the zinc finger gene family [23]. TFIIIA transcription factor was first found in Xenopus laevis [24]. In plants, C2H2-type zinc finger proteins have a highly conserved amino acid sequence (QALGGH) located at the junction of the zinc finger and the DNA $\alpha$ Spiral zone [25]. In addition to the typical zinc finger domain that binds to DNA, most $\mathrm{C} 2 \mathrm{H} 2$-type zinc finger proteins also contain three characteristic motifs $[17,26]$. One is the ERF-associated amphiphilic repression (EAR) motif (also known as DLN-box)—a short hydrophobic transcriptional repressor domain near the C-terminal. The second is a nuclear localization signal (NLS) - mainly related to subcellular localization. The third is an L-box-possibly related to protein interactions.

The $\mathrm{C} 2 \mathrm{H} 2$-type zinc finger proteins play an important role in the growth and development of plants [27-29]. In Arabidopsis, JAGGED (JAG) can regulate cell differentiation and flower morphological development [30]. ZINC FINGER of ARABIDOPSIS THALIANA 6 (ZAT6) plays an important role in the regulation of anthocyanin under hydrogen peroxide treatment [18]. ZINC FINGER PROTEIN 5 (ZFP5) can affect root hair development by directly regulating root hair development-related genes [31]. In addition, it also plays an important role in abiotic stress [32,33]. AtZAT18 positively regulates plant drought tolerance, while its mutant decreased the tolerance to drought stress in Arabidopsis [34]. Triticum aestivum predicted that Dof zinc finger protein (TaZNF) regulates salt tolerance [35]. Ectopic expression of GmZFP3 in Arabidopsis plays a negative regulatory role in drought response [36]. Oryza sativa drought-responsive zinc finger protein 1 (OsDRZ1) overexpression in rice can improve plant drought tolerance by accumulating more proline and scavenging ROS [37]. A multi-stress-responsive gene (OsMSR15) in Oryza sativa L. shows positive regulation in cold, drought, and heat stress conditions at various developmental stages of rice [38]. MdZAT10 positively regulates JA-induced leaf senescence by interacting with MdBT2 (BTB-TAZ 2) and negatively regulates plant drought tolerance in apple [39,40].

So far, $\mathrm{C} 2 \mathrm{H} 2$-type zinc finger proteins have been widely cloned and identified in Arabidopsis. However, ZAT5 has been rarely reported in other species, and its function in apple is poorly understood. In this assay, we identified a C2H2-type zinc finger protein transcription factor MdZAT5 in apple and characterized its roles in regulating apple calli and transgenic Arabidopsis anthocyanin accumulation and salt stress.

\section{Results}

\subsection{Identification and Bioinformatics Analysis of the MdZAT5 Gene in Apple}

MdZAT5 (MD03G1128800) was identified as the closest apple homolog of the C2H2type zinc finger transcription factor AtZAT5 (At2G28200) on the NCBI database. Its fulllength cDNA was 969 bp long and encoded 322 aa. As shown in Figure 1A, it contained two conserved zinc finger domains. We predicted the secondary structure of MdZAT5 protein and found that it was mainly random coils $(69.88 \%)$, followed by alpha-helices $(14.29 \%)$, extended-strands (12.73\%), and beta-turns (3.11\%) (Figure 1B). Based on the prediction results of the secondary structure, the tertiary structure was predicted (Figure 1C).

\subsection{Phylogenetic and Conserved Motif Analysis of ZAT5 Proteins from Different Plants}

In order to analyze the phylogenetic relationship between MdZAT5 protein and ZAT5 proteins of other species, an evolutionary tree was constructed using MEGA_X software. It was found that the ZAT5 protein of apple (Malus domestica) showed the closest evolutionary relationship with pear (Pyrus $\times$ bretschneideri and Pyrus ussuriensis $\times$ Pyrus communis) (Figure 2A). In addition, we compared the ZAT5 protein sequences of apple and the other nine species and found that they all contained two conserved zinc finger domains and an EAR motif (Figure 2B). 
A

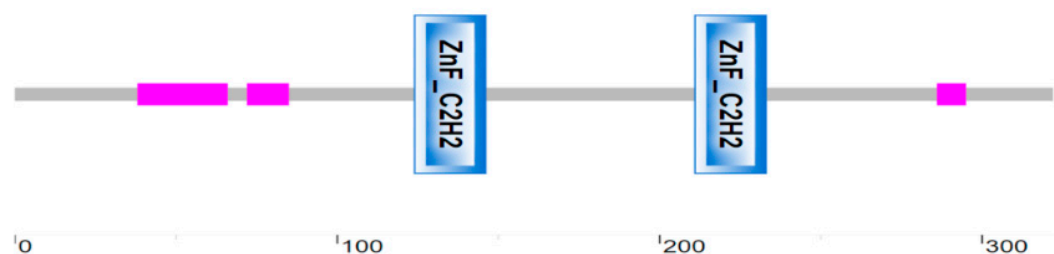

B
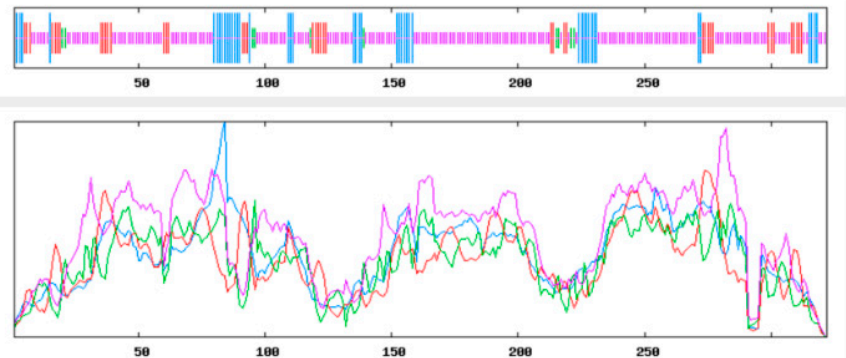

$\mathrm{C}$

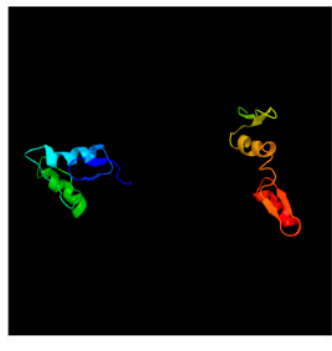

Figure 1. Basic information about the MdZAT5 sequence. (A) Conserved sequence of MdZAT5 protein. The blue rectangle indicates the zinc finger domain. The numbers represent the length of amino acids. $(\mathbf{B}, \mathbf{C})$ predicted the secondary and tertiary protein structures of MdZAT5, respectively. The numbers denote the length of amino acids.

A

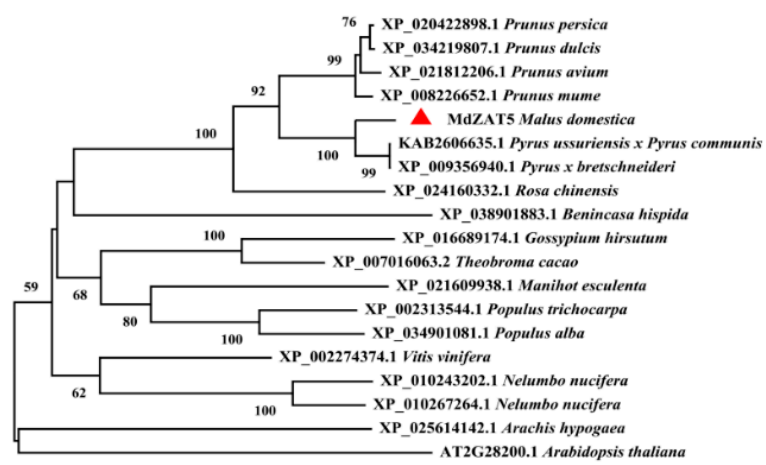

B

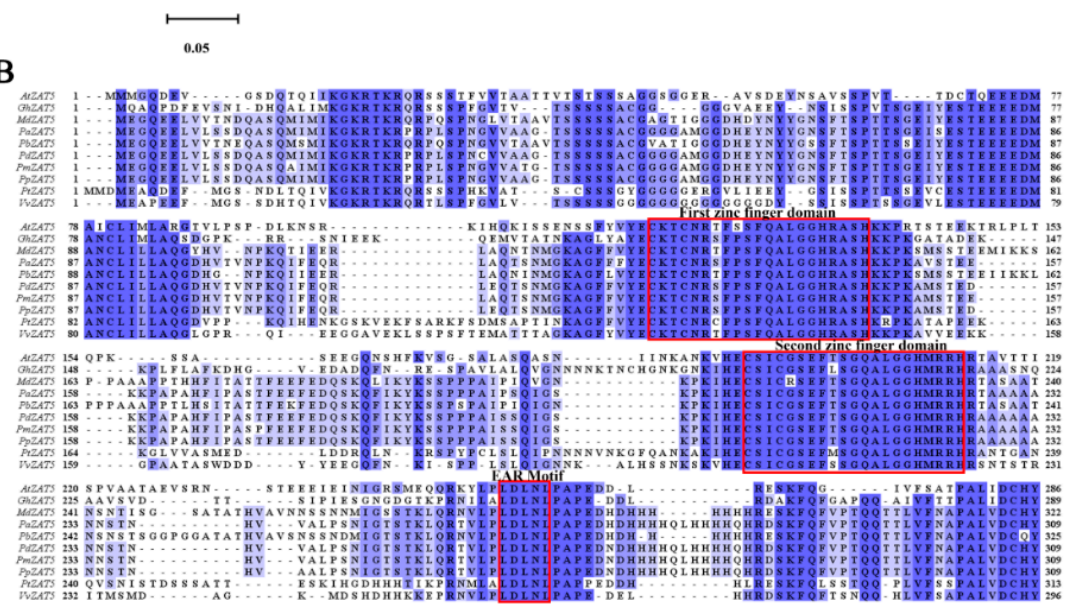

Figure 2. Phylogenetic tree, amino acid sequence alignment, and conserved motifs analysis. (A) The phylogenetic tree of ZAT5 proteins from 18 different plants. (B) Comparison of amino acid sequences of ZAT5 proteins from 10 different plants. The red triangle represents MdZAT5. The red box represents a conserved domain. They all have two conserved zinc finger domains and an EAR motif. 


\subsection{Tissue Expression Pattern of MdZAT5}

To further explore the potential biological function of MdZAT5 in apple, we detected its expression in five different organ tissues of apple (roots, stems, leaves, flowers, and fruits) by qRT-PCR. MdZAT5 was expressed in organs and tissues, among which the expression was the highest in flowers, followed by stems and leaves, and lower in roots and fruits (Figure 3A). The constructed ProMdZAT5::GUS vector was genetically transformed into Arabidopsis to obtain ProMdZAT5::GUS transgenic Arabidopsis. GUS staining showed that MdZAT5 was expressed in roots, stems, leaves, flowers, and fruits (Figure 3B), and the results were consistent with Figure $3 \mathrm{~A}$.

A

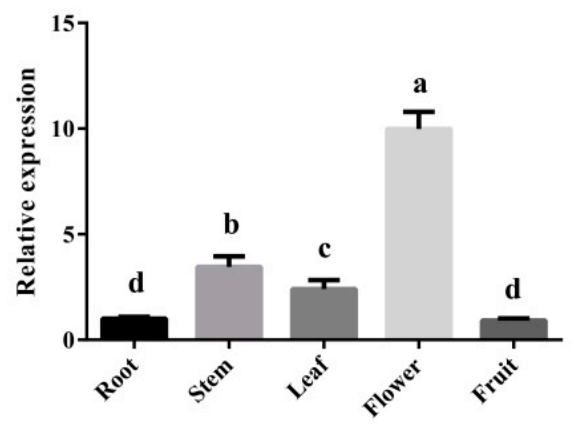

B

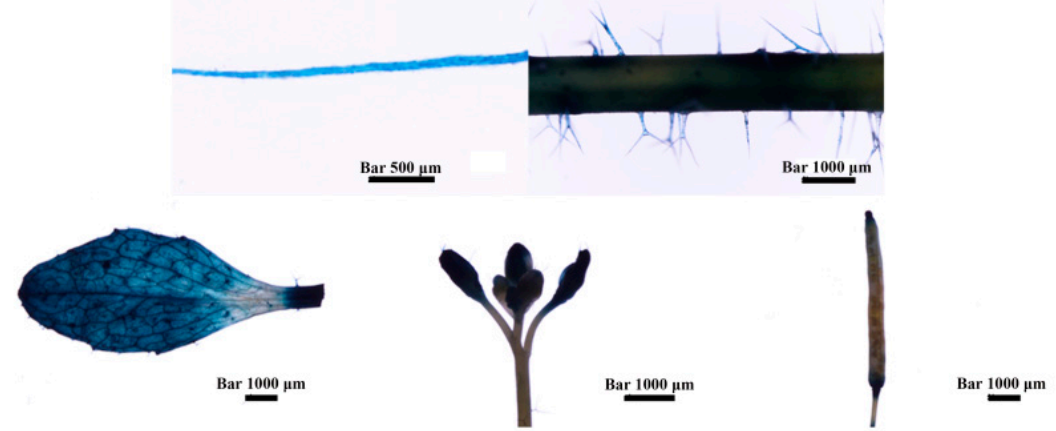

Figure 3. Tissue expression analysis of MdZAT5. (A) The relative expression level of MdZAT5 in different tissues (roots, stems, leaves, flowers, and fruits) by qRT-PCR. (B) Tissue expression analysis of MdZAT5 via GUS staining in transgenic Arabidopsis. Different lowercase letters represent a significant difference $(p<0.05)$. Data are the mean \pm SD of three independent replicates.

\subsection{Cis-Elements Analysis of MdZAT5 Promoter Sequence and Expression Patterns of MdZAT5}

We analyzed MdZAT5 cis-elements in promoter $2000 \mathrm{bp}$ upstream using the PlantCARE online software. There are various response elements in the MdZAT5 promoter (Table 1), such as cis-elements in response to plant hormones: abscisic responsive element (ABRE) and MeJA responsive element (CGTCA-motif). A large number of light response elements is known in the MdZAT5 promoter, such as Box 4, G-Box, GATA-motif, GT1-motif, MRE, and TCCC-motif. In addition, there is an ARE element that responds to hypoxia in the MdZAT5 promoter.

Table 1. Cis-elements analysis of MdZAT5 promoter regions.

\begin{tabular}{|c|c|c|c|}
\hline Cis-Element Name & $\begin{array}{l}\text { Cis-Element } \\
\text { Sequence }\left(5^{\prime}-3^{\prime}\right)\end{array}$ & Function & Location \\
\hline ABRE & ACGTG & $\begin{array}{l}\text { cis-acting element involved in the abscisic acid } \\
\text { responsiveness }\end{array}$ & +550 \\
\hline CGTCA-motif & CGTCA & $\begin{array}{l}\text { cis-acting regulatory element involved in the } \\
\text { MeJA-responsiveness }\end{array}$ & -1649 \\
\hline ARE & AAACCA & $\begin{array}{l}\text { cis-acting regulatory element essential for the anaerobic } \\
\text { induction }\end{array}$ & +1006 \\
\hline Box 4 & ATTAAT & $\begin{array}{l}\text { part of a conserved DNA module involved in light } \\
\text { responsiveness }\end{array}$ & +245 \\
\hline G-Box & CACGTG & $\begin{array}{l}\text { cis-acting regulatory element involved in light } \\
\text { responsiveness }\end{array}$ & +550 \\
\hline GATA-motif & AAGGATAAGG & part of a light-responsive element & -1583 \\
\hline GT1-motif & GGTTAA & light-responsive element & +20 \\
\hline MRE & AACCTAA & MYB binding site involved in light responsiveness & -17 \\
\hline
\end{tabular}


To gain further insight into the expression patterns of MdZAT5 with multiple abiotic stressors, we measured the expression of the MdZAT5 gene under $\mathrm{NaCl}$ (150 mM), PEG6000 $(10 \%)$, temperature $\left(4^{\circ} \mathrm{C}\right)$, and $\mathrm{ABA}(100 \mu \mathrm{M})$ treatments. Under treatment with $150 \mathrm{mM}$ $\mathrm{NaCl}$, the expression of $M d Z A T 5$ reached its highest at $12 \mathrm{~h}$, and the overall trend was first decreasing and then increasing (Figure 4A). In response to $10 \%$ PEG 6000, the expression of $M d Z A T 5$ reached its highest at $12 \mathrm{~h}$ (Figure 4B). Under low temperature conditions $\left(4^{\circ} \mathrm{C}\right)$, $M d Z A T 5$ showed a downward trend first and then an upward trend, reaching its maximum at $12 \mathrm{~h}$ (Figure 4C). The expression of MdZAT5 showed an upward trend with the treatment of $100 \mu \mathrm{M}$ ABA over time (Figure 4D). These results showed that MdZAT5 expression was caused by different stressors, which meant that MdZAT5 played an important regulatory role in the process of stress response.

A

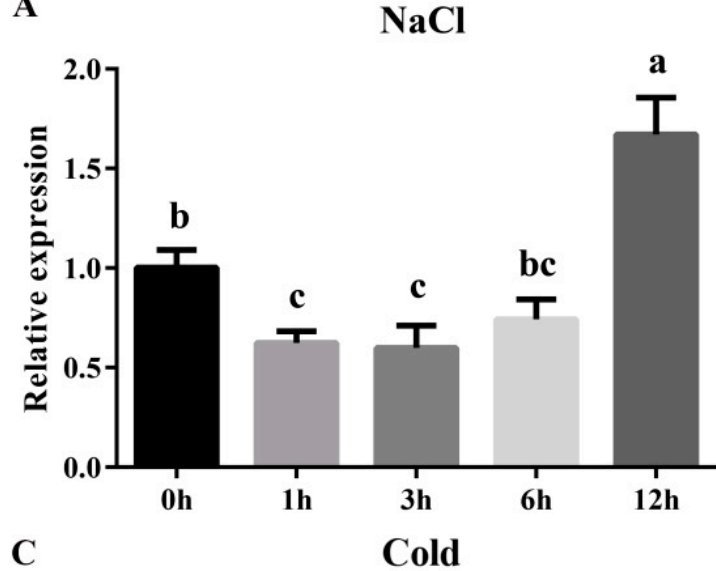

C

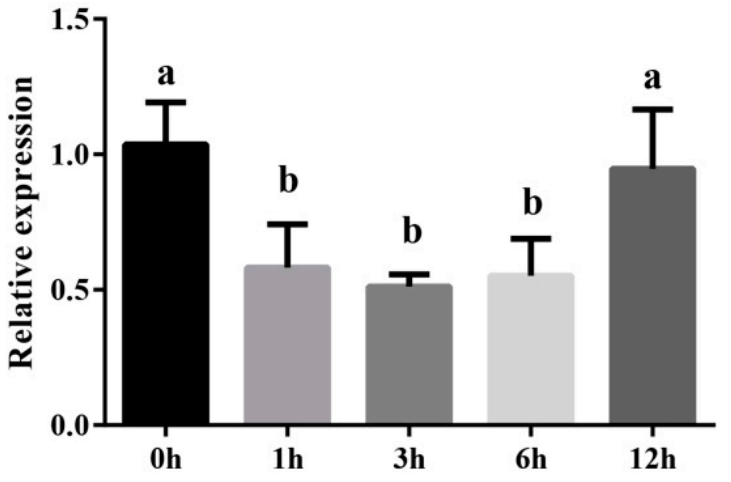

B

PEG

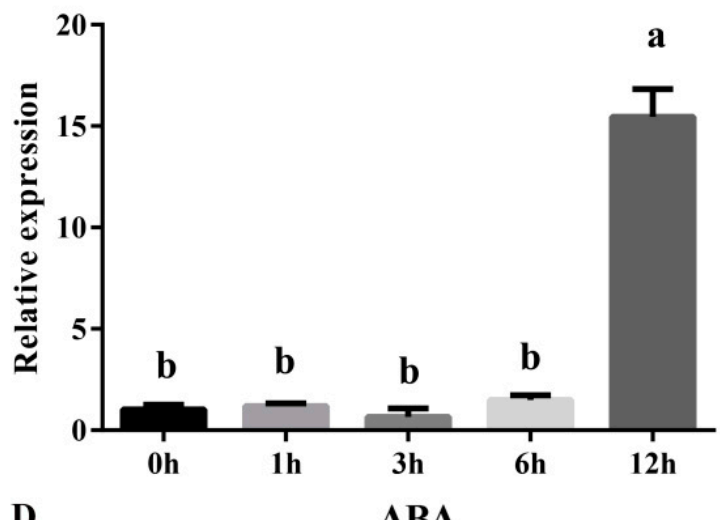

D

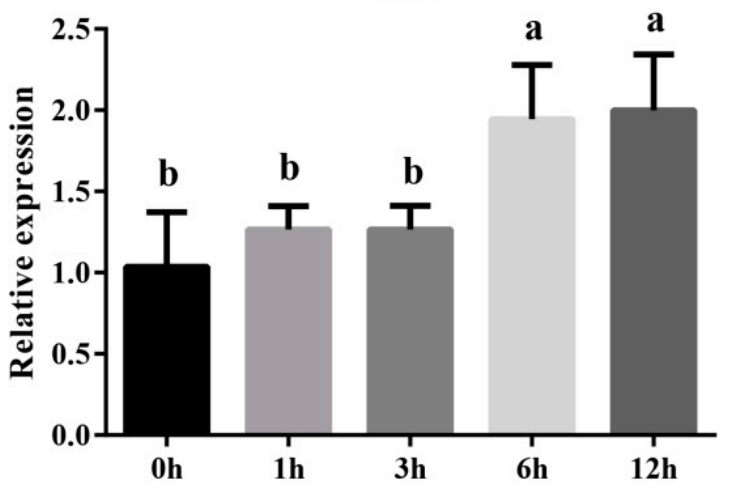

Figure 4. The expression pattern of MdZAT5 under different treatment conditions. The relative expression of MdZAT5 in $150 \mathrm{mM} \mathrm{NaCl}$ (A), 10\% PEG6000 (B), $4{ }^{\circ} \mathrm{C}(\mathbf{C})$, and $100 \mu \mathrm{M} \mathrm{ABA}(\mathbf{D})$, respectively. Different lowercase letters represent a significant difference $(p<0.05)$. Data are the mean $\pm \mathrm{SD}$ of three independent replicates.

\subsection{The Abiotic Stress Response of MdZAT5}

Based on the analysis of cis-acting elements and expression patterns, we treated ProMdZAT5::GUS transgenic Arabidopsis with different treatment conditions. Compared with the control, $150 \mathrm{mM} \mathrm{NaCl}, 6 \%$ PEG6000, and high light could significantly promote GUS activity, but at $4{ }^{\circ} \mathrm{C}$, it was lightly stained. Moreover, we found that $100 \mu \mathrm{M} \mathrm{ABA}$ caused no significant changes in leaf color relative to the control (Figure 5A). In addition, we also observed that the staining was deeper in older leaves and less intense in younger leaves, indicating that MdZAT5 was expressed higher with leaf age. We obtained ProMdZAT5::GUS transgenic calli, and their staining results were consistent with that of ProMdZAT5::GUS transgenic Arabidopsis (Figure 5A-C). 
A

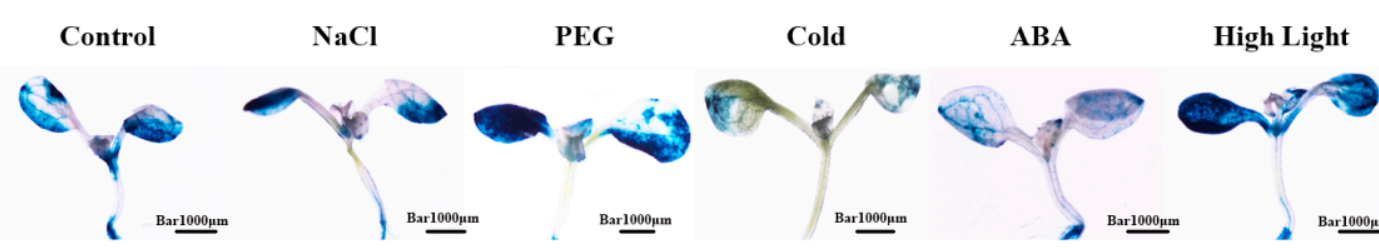

B
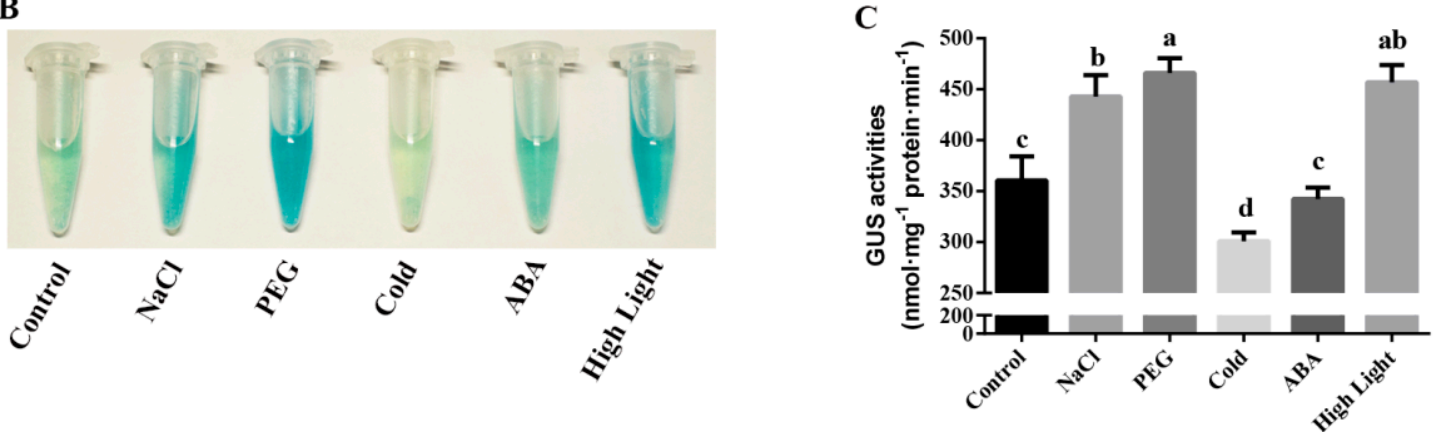

Figure 5. GUS staining in ProMdZAT5::GUS transgenic calli and Arabidopsis. The ProMdZAT5::GUS transgenic Arabidopsis (A) and calli (B), treated with $24{ }^{\circ} \mathrm{C}, 150 \mathrm{mM} \mathrm{NaCl}, 6 \% \mathrm{PEG}, 4{ }^{\circ} \mathrm{C}, 100 \mu \mathrm{M}$ ABA, and high light. (C) The GUS activity of MdZAT5 of (B). Different lowercase letters represent a significant difference $(p<0.05)$. Data are the mean \pm SD of three independent replicates.

\subsection{Overexpression of MdZAT5 in Apple Calli and Arabidopsis Promoted the Accumulation} of Anthocyanin

To study the function of MdZAT5, we constructed the MdZAT5 overexpression vector and transferred it into apple calli. Wild-type calli (WT) and transgenic apple calli (MdZAT5OVX) were cultured under high light for 18 days. As shown in Figure 6A, MdZAT5-OVX accumulated more anthocyanins, while WT accumulated less anthocyanins. At the same time, we used a spectrophotometer to quantitatively determine the content of anthocyanin. The results also showed that the anthocyanin content of MdZAT5-OVX was higher than that of WT (Figure 6B). In addition, the expression levels of flavonoid structural genes in WT and MdZAT5-OVX were analyzed by qRT-PCR. The results showed that compared with WT, the expression levels of anthocyanin biosynthesis-related genes (MdANR, MdCHI, $M d C H S, M d D F R, M d F 3 H$, and MdUFGT) increased by different degrees (Figure 6C).

In addition, we genetically transformed the constructed MdZAT5 overexpression vector into Arabidopsis (Columbia ecotype) and obtained three overexpression lines (OE1, OE2, and OE3) (Figure 6F). Comparing the anthocyanin content of Col-0 and MdZAT5-OE, it was found that under high light, the anthocyanin content accumulated by the three overexpression lines was significantly higher than that of Col-0 (Figure 6G).

\subsection{MdZAT5 Increased Sensitivity to Salt Stress in Transgenic Apple Calli and Arabidopsis}

To further explore the function of MdZAT5 under abiotic stress, the 16-day-old WT and MdZAT5-OVX were transferred to $100 \mathrm{mM} \mathrm{NaCl}$ MS medium. As shown in Figure 7A, the growth rate of MdZAT5-OVX was much lower than that of WT in $100 \mathrm{mM} \mathrm{NaCl}$. Meanwhile, the fresh weight of MdZAT5-OVX was significantly lower than that of WT, and its MDA content and relative electronic conductivity were significantly higher than that of WT (Figure 7B-D). Therefore, the overexpression of MdZAT5 negatively regulates the salt resistance of apple calli. 
A
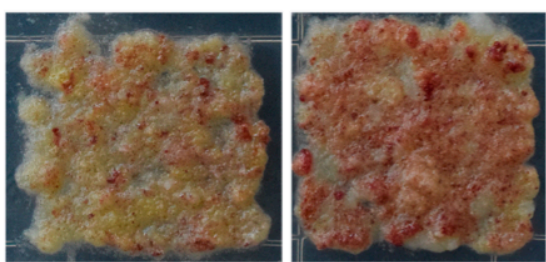

s

C

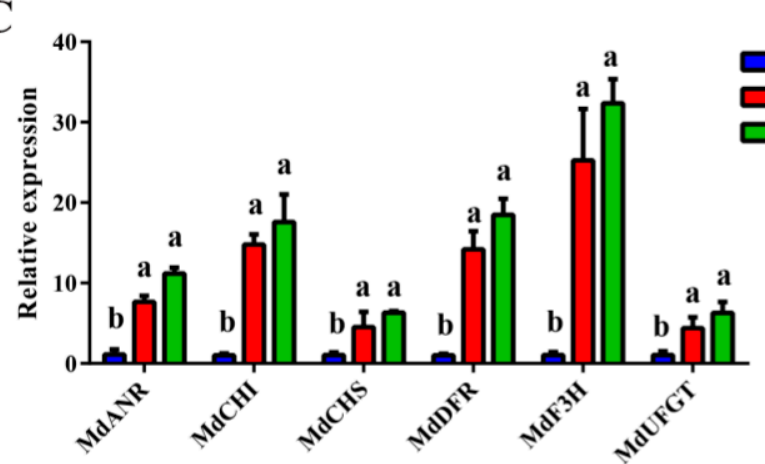

B

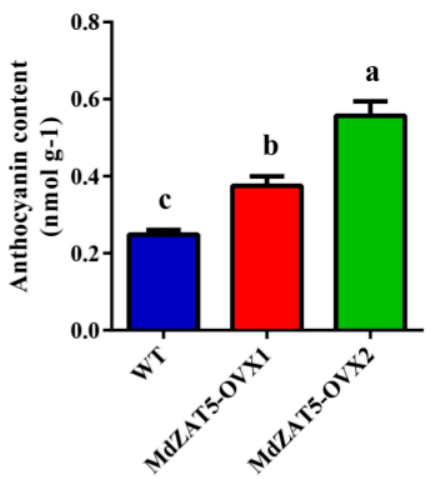

D

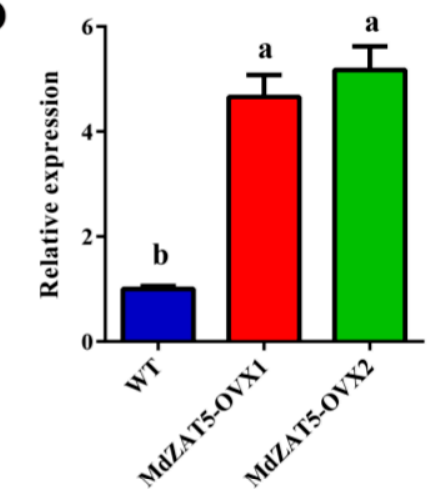

$\mathbf{E}$

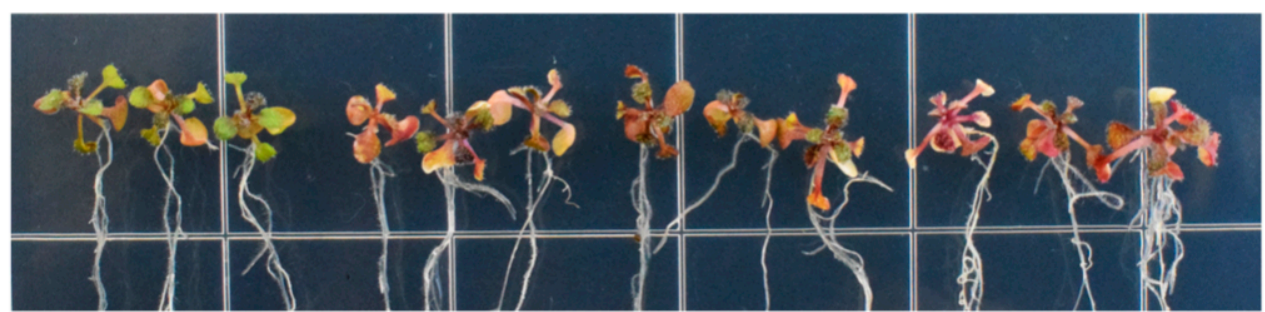

$c^{0+0}$

$\mathbf{F}$

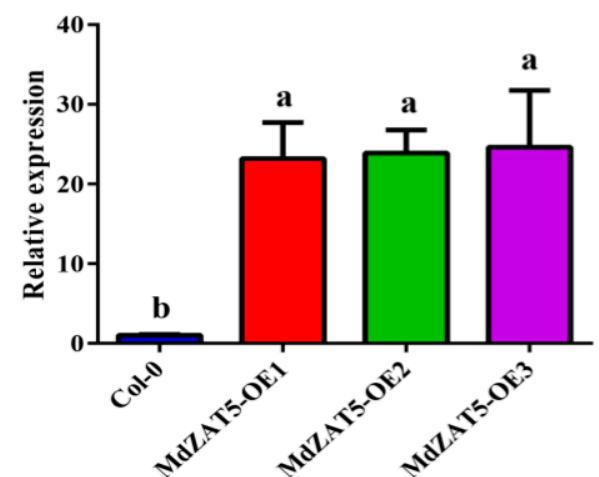

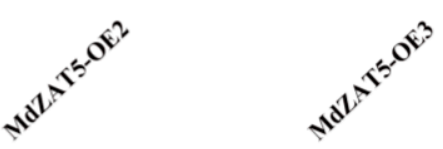

G

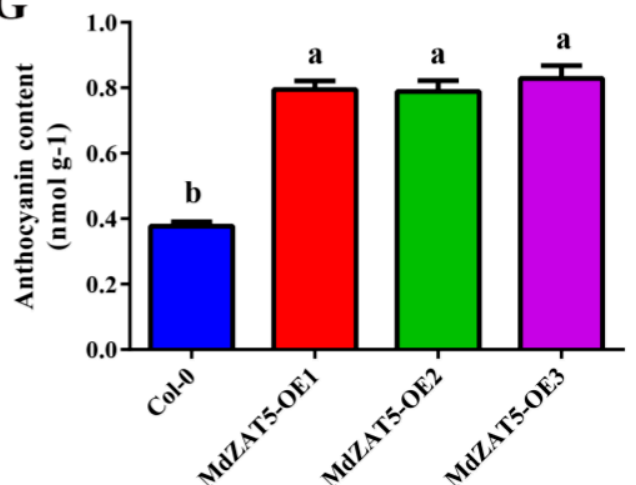

Figure 6. Overexpression of MdZAT5 in apple calli and Arabidopsis promoted anthocyanin accumulation. The phenotypes (A) and anthocyanin content (B) of WT and MdZAT5-OVX. Expression analysis of MdZAT5 (D) and genes involved in anthocyanin biosynthesis-related genes (MdANR, MdCHI, $M d C H S, M d D F R, M d F 3 H$, and MdUFGT) (C) in WT and MdZAT5-OVX. The phenotypes (E) and anthocyanin content (G) of Col-0 and MdZAT5-OE. (F) Expression analysis of MdZAT5 in Col-0 and $M d Z A T 5-O E$. Different lowercase letters represent a significant difference $(p<0.05)$. Data are the mean \pm SD of three independent replicates. 
A

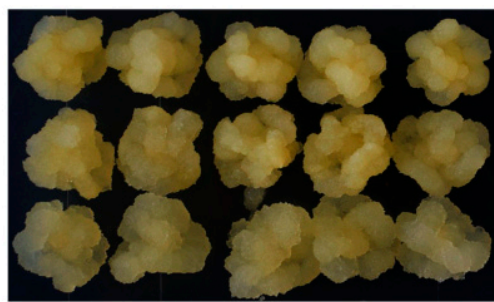

Control

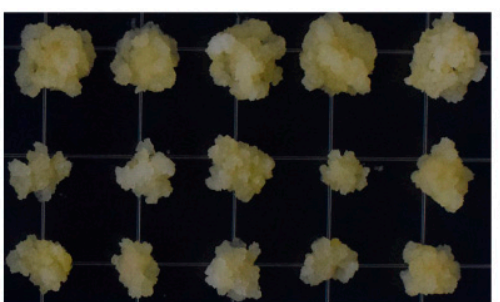

$100 \mathrm{mM} \mathrm{NaCl}$

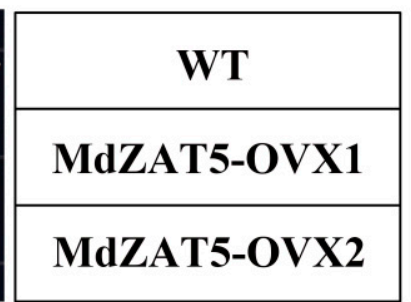

MdZAT5-OVX2
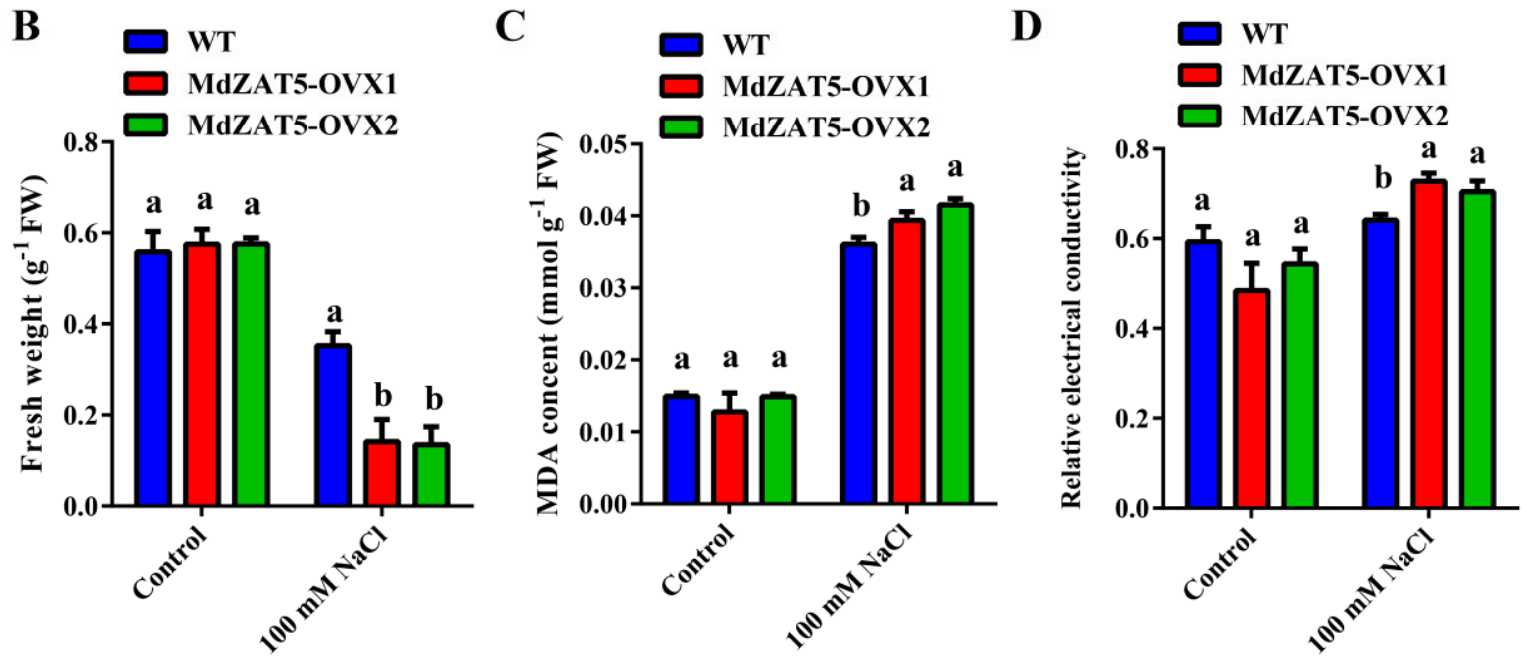

Figure 7. MdZAT5 enhanced the sensitivity to salt in apple calli. (A) The phenotypes of WT and MdZAT5-OVX with $100 \mathrm{mM} \mathrm{NaCl}$. Fresh weight (B), MDA content (C), relative electronic conductivity (D) of WT, and MdZAT5-OVX. Different lowercase letters represent a significant difference $(p<0.05)$. Data are the mean \pm SD of three independent replicates.

Furthermore, Arabidopsis seedlings (Col-0 and MdZAT5-OE) were grown on MS medium for 3 days and then transferred to $150 \mathrm{mM} \mathrm{NaCl} \mathrm{MS} \mathrm{medium} \mathrm{for} 14$ days. In the control condition, there was no significant difference in the number of lateral roots or primary root lengths. However, the number of lateral roots of MdZAT5-OE was greater than that of Col-0, and the length of primary roots was lower than that of Col-0 under the salt treatment (Figure 8B,C). In addition, we conducted salt tolerance tests on Col- 0 and transgenic plants for 14 days. As shown in Figure 8D, Col-0 grew normally, while MdZAT5$O E$ had yellow and wilting leaves. Simultaneously, the content of MDA in MdZAT5-OE was significantly higher than that in Col-0 plants under salt stress. In order to further study the role of MdZAT5 in the signal pathway of salt stress, we detected the expression levels of $A t N H X 1$ and AtABI1 in Arabidopsis by qRT-PCR. The results showed that the expression levels of AtNHX1 and AtABI1 in MdZAT5-OE Arabidopsis were significantly lower than those in Col-0 (Figure 8F,G).

\subsection{Ectopic Expression of MdZAT5 Increased ROS Accumulation under Salt Stress}

$\mathrm{H}_{2} \mathrm{O}_{2}$ levels were measured using diaminobenzidine (DAB) staining and $\mathrm{O}_{2}{ }^{-}$using nitro blue tetrazolium (NBT). In the control group, no significant difference was observed between WT and MdZAT5-OE. Under salt treatment, the staining of MdZAT5-OE was deeper, while that of Col-0 was weaker (Figure 9A,B). At the same time, we quantitatively determined $\mathrm{H}_{2} \mathrm{O}_{2}$ and $\mathrm{O}_{2}{ }^{-}$, and the results were consistent with their staining results. The contents of $\mathrm{H}_{2} \mathrm{O}_{2}$ and $\mathrm{O}_{2}{ }^{-}$of $M d Z A T 5-O E$ were significantly higher than those of Col-0 under salt stress, indicating that MdZAT5 increased sensitivity to salt stress in Arabidopsis (Figure 9C,D). 

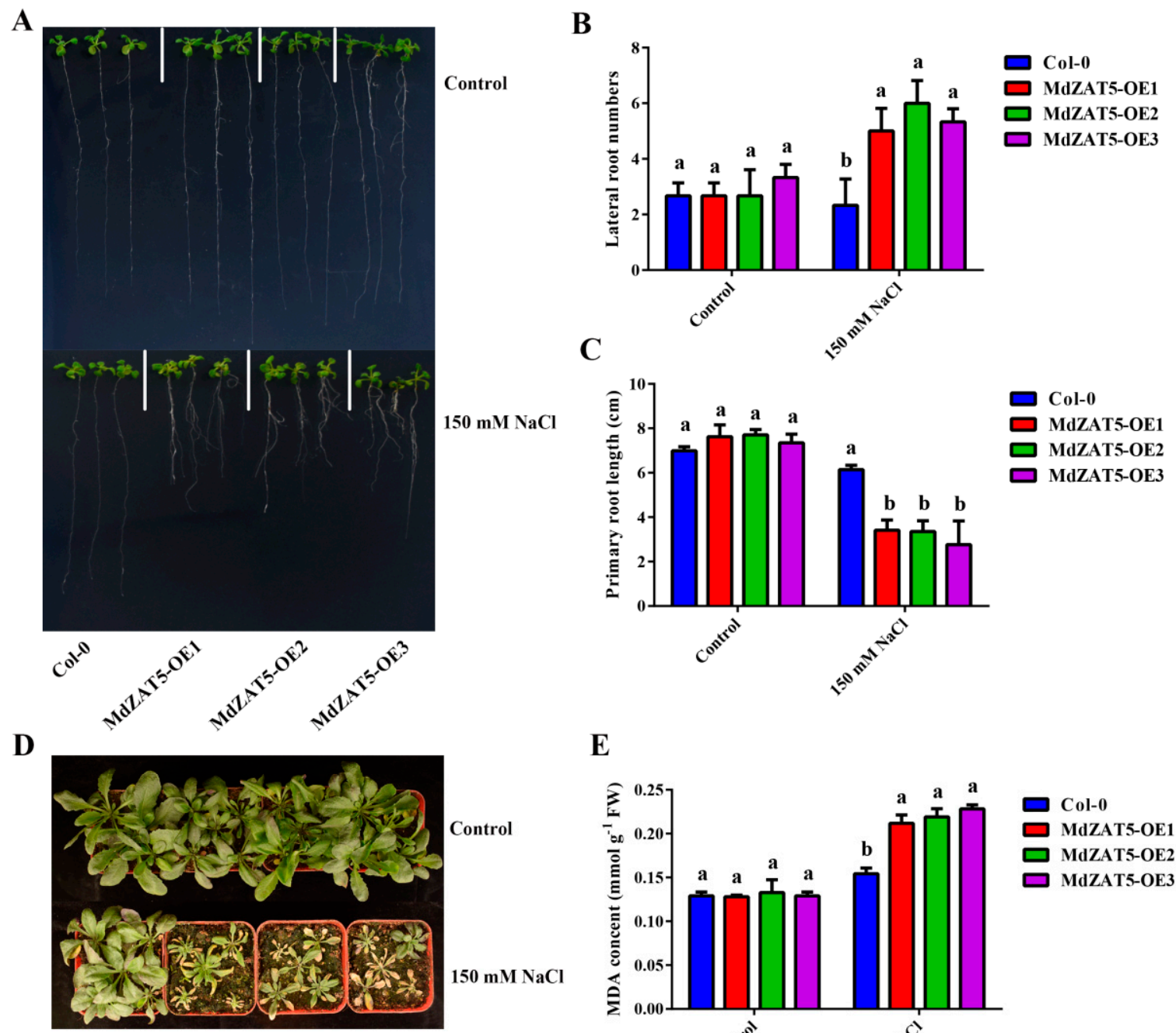

E
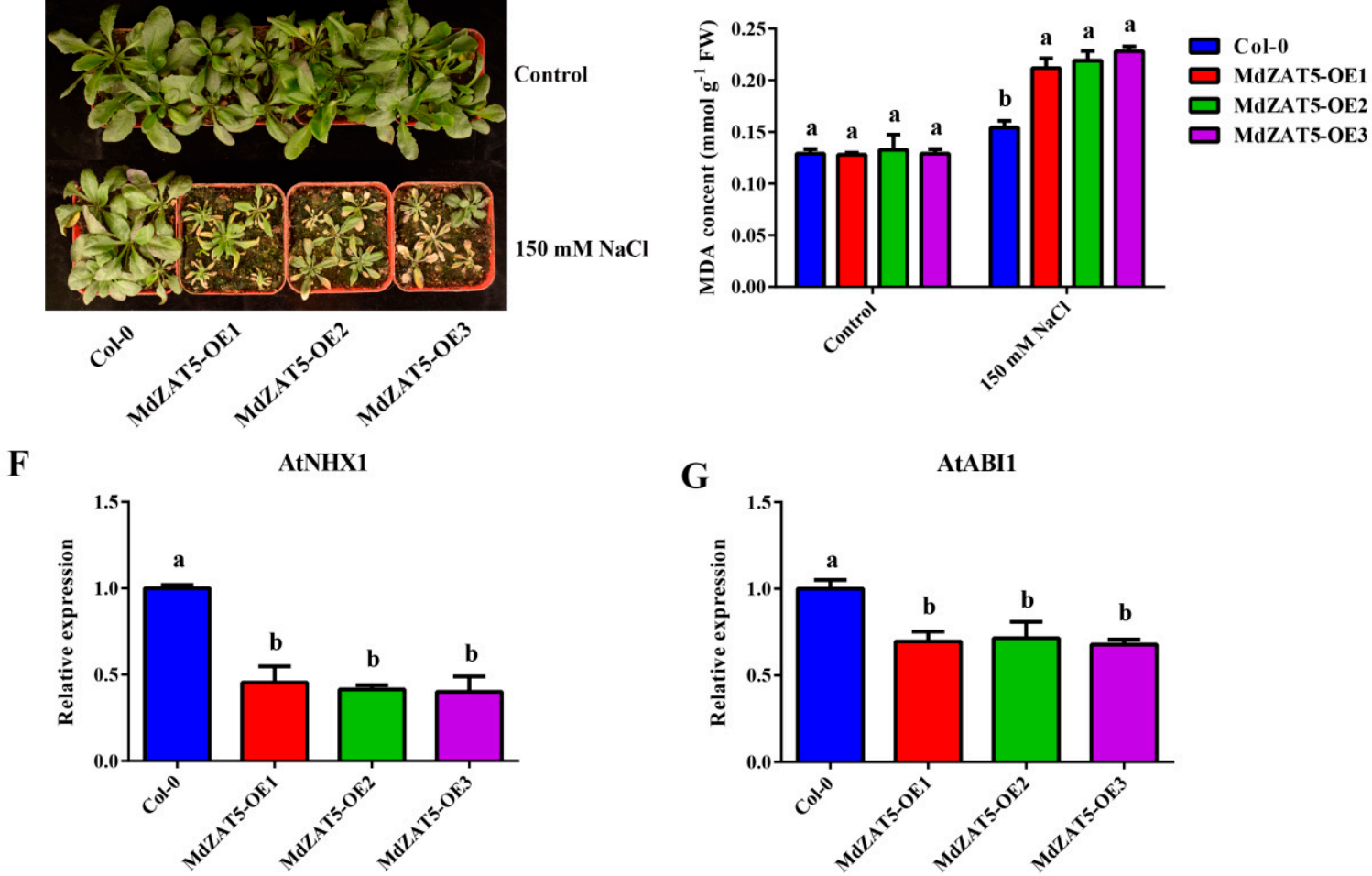

Figure 8. MdZAT5 enhanced the sensitivity to salt in transgenic Arabidopsis. (A) The phenotypes of Arabidopsis seedlings treated with MS medium, $150 \mathrm{mM} \mathrm{NaCl}$ treatment. Lateral root numbers (B) and primary root length (C) in Col-0 and MdZAT5-OE. (D) Phenotypes of Arabidopsis treated with $150 \mathrm{mM} \mathrm{NaCl}$ after 14 days and MDA content (E). The expression level of AtNHX1 (F) and AtABI1 $(\mathbf{G})$ in Col-0 and MdZAT5-OE. Different lowercase letters represent a significant difference $(p<0.05)$. Data are the mean $\pm S D$ of three independent replicates. 
A

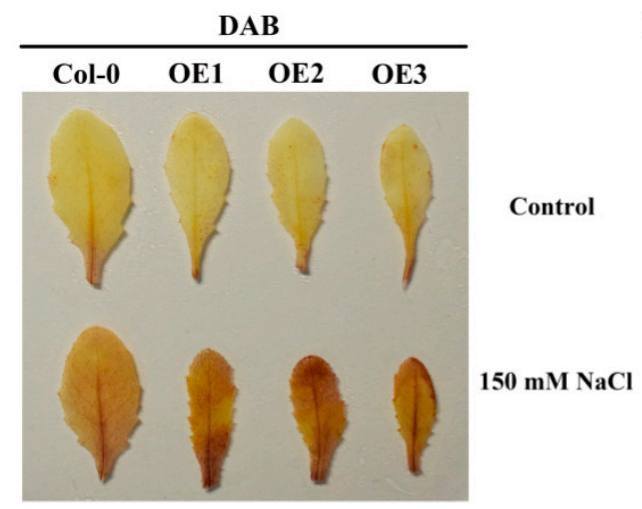

C

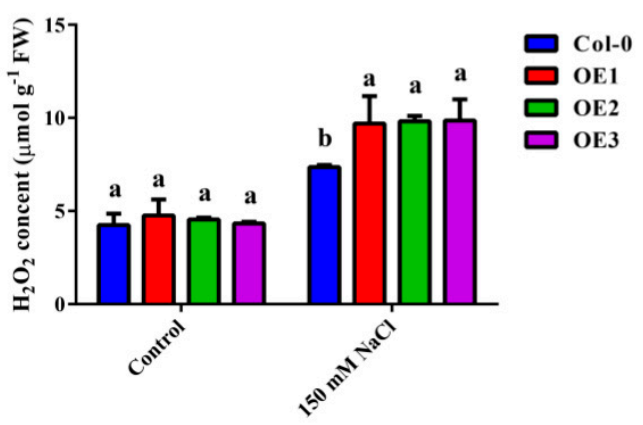

B

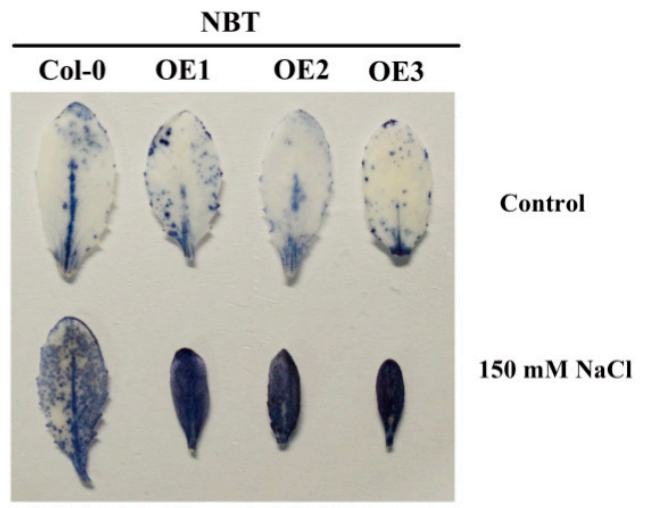

D

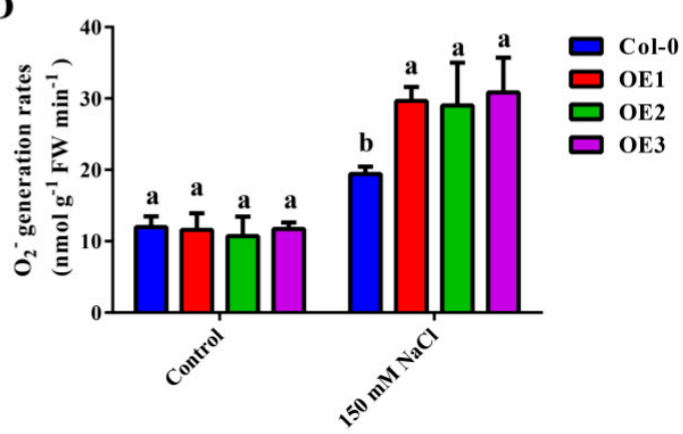

Figure 9. Ectopic expression of $M d Z A T 5$ enhances ROS buildup under salt treatment. DAB staining for $\mathrm{H}_{2} \mathrm{O}_{2}$ (A) and NBT staining for $\mathrm{O}_{2}{ }^{-}$(B) in Col-0 and MdZAT5-OE Arabidopsis leaves after 14 days of salt treatment. $\mathrm{H}_{2} \mathrm{O}_{2}$ content (C) and $\mathrm{O}_{2}{ }^{-}$generation rates (D) in Col-0 and MdZAT5-OE Arabidopsis after 14 days of salt treatment. Different lowercase letters represent a significant difference $(p<0.05)$. Data are the mean \pm SD of three independent replicates.

\section{Discussion}

$\mathrm{C} 2 \mathrm{H} 2$-type zinc finger proteins played key roles in regulating plant growth, abiotic, and biotic stress responses in plants [37,41,42]. In recent years, many studies have studied the function of $\mathrm{C} 2 \mathrm{H} 2$-type zinc finger proteins. Their functions have been widely characterized in Arabidopsis and rice. However, little has been reported in apple. Here, we isolated ZAT5 from apple and found that both ZAT5 and AtZAT5 contained two highly conserved zinc finger domains and an EAR motif, indicating that it has the conserved function of this family (Figures $1 \mathrm{~A}$ and $2 \mathrm{~B}$ ). The EAR motif, a short hydrophobic region, has been shown to function as repressor, e.g., ZAT6, STZ/ZAT10, ZAT11, and ZAT12 in Arabidopsis [43-45]. Different treatments (salt, drought, cold, ABA, and high light) induced the expression of MdZAT5, suggesting that MdZAT5 may be involved in the tolerance of many abiotic stressors (Figures 4 and 5). Previous studies have shown that AtSTZ/ZAT10 is induced by the same treatments [44,46]. MdZAT5 transgenic apple calli and Arabidopsis were confirmed to perform biological functions. In this study, MdZAT5 was involved in anthocyanin synthesis and salt stress response in apple.

Anthocyanin, a polyphenol water-soluble plant pigment, exists widely in flowers, fruits, stems, leaves, and seeds of plants [47]. Here, the expression of MdZAT5 was highest in flowers (Figure $3 \mathrm{~A}$ ). We analyzed promoter sequences of MdZAT5 and found a large number of light-responsive elements (Table 1). Light is the most important external factor regulating anthocyanin synthesis [4]. ProMdZAT5::GUS transgenic Arabidopsis was deeply up-regulated under high light treatment, consistent with the result of GUS staining of ProMdZAT5::GUS transgenic calli (Figure 5). Under high light, overexpression of MdZAT5 actively regulated anthocyanin accumulation in apple calli and Arabidopsis, further indicating that MdZAT5 plays an important role in plant response and adaptation to high light. Under high light, AtZAT12 promotes the increase of anthocyanin and chlorophyll content [48]. In Petunia, ZPT2-1 participates in anthocyanin synthesis [49]. Few studies have 
reported the functions of zinc finger proteins in the regulation of anthocyanin synthesis; thus, more work is needed in this area to perfect the content.

Salt stress is one of the most important limiting factors in plant growth, development, and yield [50,51]. Therefore, it is necessary to study salt-stress-related genes and their functions to improve crops. Previous studies have reported that many C2H2-type zinc finger proteins are involved in the regulation of salt stress as transcriptional activators or inhibitors [52]. In Arabidopsis, SALT-INDUCED ZINC FINGER PROTEIN1 (AtSIZ1) positively regulates salt tolerance by maintaining osmotic balance and ion homeostasis [53]. RING/FYVE/PHD ZFP (AtRZFP) enhances salt and osmotic tolerance by scavenging ROS, maintaining $\mathrm{Na}^{(+)}$and $\mathrm{K}^{(+)}$homeostasis [54]. AtZFP3 can enhance the salt resistance of Arabidopsis, and its expression level is inhibited under salt stress [55]. OsZFP213 interacts with OsMAPK3 to improve salt tolerance by scavenging reactive oxygen [56]. In other species, there are also reports of $\mathrm{C} 2 \mathrm{H} 2$-type zinc finger proteins involved in salt stress, such as wheat, soybean, tomato, and sweet potato [35,57-59].

In this study, ProMdZAT5::GUS transgenic Arabidopsis and calli also further confirmed that MdZAT5 was related to salt stress (Figure 5). Under salt stress, transgenic MdZAT5 apple calli and Arabidopsis showed weaker growth than wild-type plants, indicating that MdZAT5 plays a negative regulatory role in plant response and adaptation to salt stress (Figures 7 and 8). We measured the content of MDA in apple calli and Arabidopsis, and found that the MDA content of transgenic plants was higher than in those of WT plants (Figures 7C and 8E). The content of MDA can reflect the degree of stress damage to plants [60]. The accumulation of ROS was related to the content of MDA [61]. Deeper levels of DAB/NBT staining, higher $\mathrm{H}_{2} \mathrm{O}_{2}$ content levels, and higher $\mathrm{O}_{2}{ }^{-}$generation rates under salt treatment indicate that more ROS accumulation occurred in transgenic plants (Figure 9). In addition, maintaining ion balance is an important method for plants to resist salt stress [62]. $N H X 1$, a Na${ }^{+} / \mathrm{H}^{+}$antiporter located on the vacuolar membrane, plays an important role in maintaining ion homeostasis in plant cells [63]. ABI1 is a salt-stressrelated gene [64]. The AtNHX1 and AtABI1 expression levels in the overexpressed MdZAT5 Arabidopsis were significantly lower than those in Col-0 (Figure 8F,G). The above results show that overexpression of MdZAT5 enhances the sensitivity of plants to salt stress by reducing the expression level of $N H X 1$ and $A B I 1$.

In this study, we identified a novel MdZAT5 transcription factor that directly or indirectly activates the expression of anthocyanin synthesis-related genes to increase anthocyanin accumulation or reduce the expression of salt-stress-related genes to improve the sensitivity of salt stress. This study provides new insights for future research on anthocyanin accumulation and resistance to salinization and provides new candidate genes for improving apple quality and abiotic stress. However, the potential mechanism of MdZAT5 in regulating anthocyanin accumulation and salt stress is not clear. We next intend to further improve its regulatory mechanism by verifying the direct downstream protein or gene targets of MdZAT5.

\section{Materials and Methods}

\subsection{Plant Materials and Growth Conditions}

The apple (Malus $\times$ domestica 'Royal Gala') shoot cultures were stored at $25^{\circ} \mathrm{C}$ on MS solid medium containing $0.5 \mathrm{mg} / \mathrm{L}$ 6-benzylaminopurine (6-BA) and $0.5 \mathrm{mg} / \mathrm{L}$ naphthyl acetic acid (NAA) for a 16/8 h light/dark photoperiod and subcultured at 30-day intervals. To obtain self-rooted plantlets, the 3-week-old shoot cultures were transferred to a rootinducing MS solid medium containing $0.2 \mathrm{mg} / \mathrm{L}$ indoleacetic acids (IAA). For tissue expression analysis, the roots, stems, leaves, flowers, and fruits were collected 80 days after flowering from 7-year-old 'Gala' apple tree (Taian, China). Four-week-old self-rooted apple seedlings were treated with $\mathrm{NaCl}(150 \mathrm{mM})$, PEG $6000(10 \%)$, temperature $\left(4^{\circ} \mathrm{C}\right)$, and ABA $(100 \mu \mathrm{M})$, as described in [45].

Apple calli from the 'Orin' cultivar were grown on MS solid medium of $1.5 \mathrm{mg} / \mathrm{L}$ 2, 4-dichlorophenoxyacetic acid (2, 4-D), and $0.4 \mathrm{mg} / \mathrm{L} \mathrm{6-BA}$ for 18 days in the dark at 
$24{ }^{\circ} \mathrm{C}$. Then, for the stress treatment, calli were cultured in a medium with high light and $\mathrm{NaCl}(100 \mathrm{mM})$ for 18 days. The seeds of ecotype Columbia (Col-0) and transgenic Arabidopsis (MdZAT5-OE1, MdZAT5-OE2, MdZAT5-OE3) were sterilized and vernalized for 3 days at $4{ }^{\circ} \mathrm{C}$. Then, Arabidopsis seedlings were sown on MS solid medium for 3 days under a photoperiod of $16 / 8 \mathrm{~h} \mathrm{light/dark}$ and transferred to solid medium with high light $\left(\sim 300 \mu \mathrm{mol} \mathrm{m}^{-2} \mathrm{~s}^{-1}\right)$ and $\mathrm{NaCl}(150 \mathrm{mM})$ for 7 and 14 days, respectively. Twenty-one-dayold seedlings of Arabidopsis were supplied with $150 \mathrm{mM} \mathrm{NaCl}$ for 14 days in soil.

\subsection{Bioinformatics Analysis of the MdZAT5 Gene}

The basic information of the MdZAT5 sequence came from the NCBI database (https: / / www.ncbi.nlm.nih.gov/, accessed on 3 November 2020). The secondary and tertiary structure prediction of MdZAT5 adopted SOPMA (https://npsa-prabi.ibcp.fr/cgi-bin/ npsa_automat.pl?page=npsa_sopma.html, accessed on 15 March 2021) and Phyre2 (http: / / www.sbg.bio.ic.ac.uk/ phyre2/html/page.cgi?id=index, accessed on 15 March 2021), respectively [65].

\subsection{Phylogenetic Analysis and Multiple Sequence Alignment of ZAT5 Proteins}

The adjacency algorithm of the online software MEGA_X was used to construct ZAT5 evolutionary neighbor-joining trees of different plants (the step test was set to 1000 times, substitution method was the Poisson model) [66]. A multiple sequence alignment of ZAT5 proteins from 10 different plants was performed using Clustal Omega. We found several highly conserved domains, which were visualized by the online software Jalview.

\subsection{Analysis of the MdZAT5 Promoter}

The cis-element in the MdZAT5 promoter (2000 bp upstream of the transcription initiation site) was analyzed with the online software PlantCARE (http:/ /bioinformatics. psb.ugent.be/webtools/plantcare/html/, accessed on 18 March 2021) [67].

\subsection{RNA Extraction and $q R T-P C R$ Assays}

Total RNAs of plant materials, including apple and Arabidopsis, were isolated using the RNA Plant Plus Reagent Kit (Tiangen Biotech, Beijing, China). Reverse transcription was conducted for single-stranded DNA synthesis using the PrimScript ${ }^{\mathrm{TM}}$ First Strand cDNA Synthesis Kit (TaKaRa, Dalian, China), per the manufacturer's protocol. qRT-PCR was performed on the extracted RNA using an ABI7500, in which $18 S$ (apple) and AtACTIN (Arabidopsis) were used as internal control. Then, relative gene expression analysis was conducted using the cycle threshold $(\mathrm{Ct}) 2^{-\Delta \Delta \mathrm{CT}}$ method. Quantitative primers are listed in Supplementary Table S1.

\subsection{Construction of the Expression Vectors and Genetic Transformation}

To construct the overexpression vector of MdZAT5, we cloned the full-length coding sequence of MdZAT5 into the plant expression vector pRI101 [40]. The MdZAT5 (2000 bp promoter fragment from start codon) was cloned into a p1300-GN vector to construct ProMdZAT5::GUS, and the vector drives Gus ( $\beta$-glucuronidase) reporter gene [64]. The MdZAT5 overexpression vector and ProMdZAT5::GUS constructs were transformed into Arabidopsis by the flower dipping method to obtain transgenic plants [68]. The calli of transgenic apple were obtained by the Agrobacterium-mediated method [69]. Transgenic Arabidopsis and calli were identified with kanamycin.

\subsection{GUS Histochemical Staining}

The 18-day-old transgenic apple calli and 7-day-old transgenic Arabidopsis seedlings of ProMdZAT5::GUS were cultured on solid medium with $\mathrm{NaCl}(150 \mathrm{mM})$, PEG $6000(10 \%)$, temperature $\left(4{ }^{\circ} \mathrm{C}\right), \mathrm{ABA}(100 \mu \mathrm{M})$, and high light $\left(\sim 300 \mu \mathrm{mol} \mathrm{m}^{-2} \mathrm{~s}^{-1}\right)$ for $24 \mathrm{~h}$. Apple calli or Arabidopsis seedlings were subjected to staining using GUS staining buffer (containing 
$0.5 \mathrm{mM}$ ferrocyanide, $0.1 \%$ Triton $\mathrm{X}-100,0.1 \mathrm{mM}$ EDTA, $0.5 \mathrm{mM}$ ferricyanide, and $1 \mathrm{mM}$ $\mathrm{X}$-Gluc) and then decolorized with absolute ethanol for $12 \mathrm{~h} \mathrm{[70].}$

\subsection{Measurements of Anthocyanin, Relative Electronic Conductivity, and MDA}

The anthocyanin of plants was extracted by the methanol hydrochloric acid method [71]. The plant materials were placed in anthocyanin extract $(95 \%$ ethanol: $1.5 \mathrm{M} \mathrm{HCl}=85: 15$, $v / v$ ) in the dark at room temperature for $24^{\circ} \mathrm{C}$. The absorbance value of the extracted samples was measured at 530,620, and $650 \mathrm{~nm}$ with a UV-Vis spectrophotometer. The anthocyanin content was calculated according to the previous method [72].

The relative electronic conductivity content of apple calli was measured by this method and a DDS-12 conductometer (Hangzhou Wanda Instrument Factory, Hangzhou, China) [73]. The content of MDA in apple calli and Arabidopsis was determined by the thiobarbituric acid (TBA)-based method [74].

\subsection{Measurement of ROS}

The $\mathrm{H}_{2} \mathrm{O}_{2}$ content and $\mathrm{O}_{2}{ }^{-}$production rate were determined using a kit (Keming, Suzhou, China). $\mathrm{H}_{2} \mathrm{O}_{2}$ level was detected by diaminobenzidine (DAB) histochemical staining, and $\mathrm{O}_{2}{ }^{-}$level was detected by nitro blue tetrazolium (NBT) staining in accordance with the methods described in [75].

\subsection{Statistical Analysis}

Each experiment was repeated at least three times (biological repetitions). Each biological repetition was performed at least three times (technical repetitions). All Data processing system (DPS) was used to analyze the significance of the data [76].

\section{Conclusions}

In short, overexpression of MdZAT5 promotes the expressions of anthocyanin biosynthesis-related genes to actively regulate anthocyanin synthesis and increase sensitivity to salt stress by regulating the expression of $N H X 1$ and $A B I 1$. Our study provides new insight into MdZAT5-mediated anthocyanin synthesis and salt resistance and is helpful to further clarify the mechanism of anthocyanin synthesis and salt stress.

Supplementary Materials: The following are available online at https://www.mdpi.com/article/10 $.3390 /$ ijms23031897/s1.

Author Contributions: Data curation, D.-R.W.; formal analysis, K.Y., X.W., X.-L.L., L.R., H.-F.L.; funding acquisition, D.-D.L. and C.-X.Y.; investigation, D.-D.L. and C.-X.Y.; resources, C.-X.Y.; visualization, D.-R.W. and K.Y.; writing-original draft, D.-R.W.; conceptualization, D.-D.L.; writingreview and editing, D.-R.W. and D.-D.L. All authors have read and agreed to the published version of the manuscript.

Funding: This research was funded by the National Natural Science Foundation of China (32172538), Yunnan Province Applied Basic Research Programs of Science and Technology Department (K264202004420).

Institutional Review Board Statement: Not applicable.

Informed Consent Statement: Not applicable.

Data Availability Statement: Not applicable.

Conflicts of Interest: The authors declare no conflict of interest.

\section{References}

1. Porta, N.L.; Bertamini, M.; Nedunchezhian, N.; Muthuchelian, K. High Irradiance Induced Changes of Photosystem 2 in Young and Mature Needles of Cypress (Cupressus sempervirens L.). Photosynthetica 2004, 42, 263-271. [CrossRef]

2. Shen, H.; Luong, P.; Huq, E. The F-box protein MAX2 functions as a positive regulator of photomorphogenesis in Arabidopsis. Plant Physiol. 2007, 145, 1471-1483. [CrossRef] [PubMed]

3. Xu, D.; Li, J.; Gangappa, S.N.; Hettiarachchi, C.; Lin, F.; Andersson, M.X.; Jiang, Y.; Deng, X.W.; Holm, M. Convergence of Light and ABA signaling on the ABI5 promoter. PLoS Genet. 2014, 10, e1004197. [CrossRef] 
4. Zoratti, L.; Karppinen, K.; Luengo Escobar, A.; Häggman, H.; Jaakola, L. Light-controlled flavonoid biosynthesis in fruits. Front. Plant Sci. 2014, 5, 534. [CrossRef] [PubMed]

5. Meng, X.; Xing, T.; Wang, X. The role of light in the regulation of anthocyanin accumulation in Gerbera hybrida. Plant Growth Regul. 2004, 44, 243-250. [CrossRef]

6. Jiang, M.; Ren, L.; Lian, H.; Liu, Y.; Chen, H. Novel insight into the mechanism underlying light-controlled anthocyanin accumulation in eggplant (Solanum melongena L.). Plant Sci. 2016, 249, 46-58. [CrossRef]

7. Van Zelm, E.; Zhang, Y.; Testerink, C. Salt Tolerance Mechanisms of Plants. Annu. Rev. Plant Biol. 2020, 71, 403-433. [CrossRef]

8. Ponce, K.S.; Meng, L.; Guo, L.; Leng, Y.; Ye, G. Advances in Sensing, Response and Regulation Mechanism of Salt Tolerance in Rice. Int. J. Mol. Sci. 2021, 22, 2254. [CrossRef]

9. Yin, R.; Bai, T.; Ma, F.; Wang, X.; Li, Y.; Yue, Z. Physiological responses and relative tolerance by Chinese apple rootstocks to NaCl stress. Sci. Hortic. 2010, 126, 247-252. [CrossRef]

10. Zhang, Z.; Zeng, L.; Zhao, J.; Guo, B.; Wang, Y.; Luo, J.; Zheng, X.; Tian, X. Response to Salt Stress of Growth and Physiological Characteristic of Five Apple Rootstocks. North. Hortic. 2017, 3, 19-25.

11. Zhu, J.K. Abiotic Stress Signaling and Responses in Plants. Cell 2016, 167, 313-324. [CrossRef] [PubMed]

12. Liu, H.; Able, A.J.; Able, J.A. Priming crops for the future: Rewiring stress memory. Trends Plant Sci. 2021. [CrossRef] [PubMed]

13. Liang, W.; Ma, X.; Wan, P.; Liu, L. Plant salt-tolerance mechanism: A review. Biochem. Biophys. Res. Commun. 2018, 495, 286-291. [CrossRef] [PubMed]

14. Chen, T.; Li, W.; Hu, X.; Guo, J.; Liu, A.; Zhang, B. A Cotton MYB Transcription Factor, GbMYB5, is Positively Involved in Plant Adaptive Response to Drought Stress. Plant Cell Physiol. 2015, 56, 917-929. [CrossRef] [PubMed]

15. Jiang, J.; Ma, S.; Ye, N.; Jiang, M.; Cao, J.; Zhang, J. WRKY transcription factors in plant responses to stresses. J. Integr. Plant Biol. 2017, 59, 86-101. [CrossRef] [PubMed]

16. Kim, J.; Kim, H.Y. Functional analysis of a calcium-binding transcription factor involved in plant salt stress signaling. FEBS Lett. 2006, 580, 5251-5256. [CrossRef] [PubMed]

17. Ciftci-Yilmaz, S.; Morsy, M.R.; Song, L.; Coutu, A.; Krizek, B.A.; Lewis, M.W.; Warren, D.; Cushman, J.; Connolly, E.L.; Mittler, R The EAR-motif of the Cys2/His2-type zinc finger protein Zat7 plays a key role in the defense response of Arabidopsis to salinity stress. J. Biol. Chem. 2007, 282, 9260-9268. [CrossRef]

18. Shi, H.; Liu, G.; Wei, Y.; Chan, Z. The zinc-finger transcription factor ZAT6 is essential for hydrogen peroxide induction of anthocyanin synthesis in Arabidopsis. Plant Mol. Biol. 2018, 97, 165-176. [CrossRef]

19. Agarwal, P.K.; Agarwal, P.; Reddy, M.K.; Sopory, S.K. Role of DREB transcription factors in abiotic and biotic stress tolerance in plants. Plant Cell Rep. 2006, 25, 1263-1274. [CrossRef]

20. An, J.P.; Yao, J.F.; Xu, R.R.; You, C.X.; Wang, X.F.; Hao, Y.J. An apple NAC transcription factor enhances salt stress tolerance by modulating the ethylene response. Physiol. Plant 2018, 164, 279-289. [CrossRef]

21. An, J.P.; Zhang, X.W.; Xu, R.R.; You, C.X.; Wang, X.F.; Hao, Y.J. Apple MdERF4 negatively regulates salt tolerance by inhibiting MdERF3 transcription. Plant Sci. 2018, 276, 181-188. [CrossRef] [PubMed]

22. Huang, J.; Wang, J.F.; Zhang, H.S. Structure and function of plant C2H2 zinc finger protein. Yi Chuan 2004, 26, 414-418. [PubMed]

23. Laity, J.H.; Lee, B.M.; Wright, P.E. Zinc finger proteins: New insights into structural and functional diversity. Curr. Opin. Struct. Biol. 2001, 11, 39-46. [CrossRef]

24. Miller, J.; McLachlan, A.D.; Klug, A. Repetitive zinc-binding domains in the protein transcription factor IIIA from Xenopus oocytes. EMBO J. 1985, 4, 1609-1614. [CrossRef] [PubMed]

25. Takatsuji, H. Zinc-finger transcription factors in plants. Cell Mol. Life Sci. 1998, 54, 582-596. [CrossRef]

26. Yanover, C.; Bradley, P. Large-scale characterization of peptide-MHC binding landscapes with structural simulations. Proc. Natl. Acad. Sci. USA 2011, 108, 6981-6986. [CrossRef] [PubMed]

27. Li, J.; Wang, Y.; Zhang, Y.; Wang, W.; Irish, V.F.; Huang, T. RABBIT EARS regulates the transcription of TCP4 during petal development in Arabidopsis. J. Exp. Bot. 2016, 67, 6473-6480. [CrossRef]

28. Yan, A.; Wu, M.; Zhao, Y.; Zhang, A.; Liu, B.; Schiefelbein, J.; Gan, Y. Involvement of C2H2 zinc finger proteins in the regulation of epidermal cell fate determination in Arabidopsis. J. Integr. Plant Biol. 2014, 56, 1112-1117. [CrossRef] [PubMed]

29. Li, Z.; Peng, J.; Wen, X.; Guo, H. Gene network analysis and functional studies of senescence-associated genes reveal novel regulators of Arabidopsis leaf senescence. J. Integr. Plant Biol. 2012, 54, 526-539. [CrossRef] [PubMed]

30. Wei, W.; Hongyang, Y.U.; Tengbo, H.; Henghui, H.E.; Yongxia, Z. JAG's regulation in controlling the chlorophyll a/chlorophyll b ratio in Arabidopsis floral organ. J. Shenzhen Univ. (Sci. Eng.) 2018, 35, 7.

31. An, L.; Zhou, Z.; Sun, L.; Yan, A.; Xi, W.; Yu, N.; Cai, W.; Chen, X.; Yu, H.; Schiefelbein, J.; et al. A zinc finger protein geneZFP5integrates phytohormone signaling to control root hair development in Arabidopsis. Plant J. 2012, 72, $474-490$. [CrossRef]

32. Sakamoto, H.; Araki, T.; Meshi, T.; Iwabuchi, M. Expression of a subset of the Arabidopsis Cys(2)/His(2)-type zinc-finger protein gene family under water stress. Gene 2000, 248, 23-32. [CrossRef]

33. Tian, Z.D.; Zhang, Y.; Liu, J.; Xie, C.H. Novel potato C2H2-type zinc finger protein gene, StZFP1, which responds to biotic and abiotic stress, plays a role in salt tolerance. Plant Biol. 2010, 12, 689-697. [CrossRef]

34. Yin, M.; Wang, Y.; Zhang, L.; Li, J.; Quan, W.; Yang, L.; Wang, Q.; Chan, Z. The Arabidopsis Cys2/His2 zinc finger transcription factor ZAT18 is a positive regulator of plant tolerance to drought stress. J. Exp. Bot. 2017, 68, 2991-3005. [CrossRef] 
35. Ma, X.; Liang, W.; Gu, P.; Huang, Z. Salt tolerance function of the novel C2H2-type zinc finger protein TaZNF in wheat. Plant Physiol. Biochem. 2016, 106, 129-140. [CrossRef]

36. Zhang, D.; Tong, J.; Xu, Z.; Wei, P.; Xu, L.; Wan, Q.; Huang, Y.; He, X.; Yang, J.; Shao, H.; et al. Soybean C2H2-Type Zinc Finger Protein GmZFP3 with Conserved QALGGH Motif Negatively Regulates Drought Responses in Transgenic Arabidopsis. Front. Plant Sci. 2016, 7, 325. [CrossRef] [PubMed]

37. Yuan, X.; Huang, P.; Wang, R.; Li, H.; Lv, X.; Duan, M.; Tang, H.; Zhang, H.; Huang, J. A Zinc Finger Transcriptional Repressor Confers Pleiotropic Effects on Rice Growth and Drought Tolerance by Down-Regulating Stress-Responsive Genes. Plant Cell Physiol. 2018, 59, 2129-2142. [CrossRef] [PubMed]

38. Zhang, X.; Zhang, B.; Li, M.J.; Yin, X.M.; Huang, L.F.; Cui, Y.C.; Wang, M.L.; Xia, X. OsMSR15 encoding a rice C2H2-type zinc finger protein confers enhanced drought tolerance in transgenic Arabidopsis. J. Plant Biol. 2016, 59, 271-281. [CrossRef]

39. Yang, K.; An, J.P.; Li, C.Y.; Shen, X.N.; Liu, Y.J.; Wang, D.R.; Ji, X.L.; Hao, Y.J.; You, C.X. The apple C2H2-type zinc finger transcription factor MdZAT10 positively regulates JA-induced leaf senescence by interacting with MdBT2. Hortic. Res. 2021, 8, 159. [CrossRef] [PubMed]

40. Yang, K.; Li, C.Y.; An, J.P.; Wang, D.R.; Wang, X.; Wang, C.K.; You, C.X. The C2H2-type zinc finger transcription factor MdZAT10 negatively regulates drought tolerance in apple. Plant Physiol. Biochem. 2021, 167, 390-399. [CrossRef] [PubMed]

41. Huang, L.; Jiang, Q.; Wu, J.; An, L.; Zhou, Z.; Wong, C.; Wu, M.; Yu, H.; Gan, Y. Zinc finger protein 5 (ZFP5) associates with ethylene signaling to regulate the phosphate and potassium deficiency-induced root hair development in Arabidopsis. Plant Mol. Biol. 2020, 102, 143-158. [CrossRef]

42. Liu, Y.; Liu, D.; Hu, R.; Hua, C.; Ali, I.; Zhang, A.; Liu, B.; Wu, M.; Huang, L.; Gan, Y. AtGIS, a C2H2 zinc-finger transcription factor from Arabidopsis regulates glandular trichome development through GA signaling in tobacco. Biochem. Biophys. Res. Commun. 2017, 483, 209-215. [CrossRef]

43. Shi, H.; Wang, X.; Ye, T.; Chen, F.; Deng, J.; Yang, P.; Zhang, Y.; Chan, Z. The Cysteine2/Histidine2-Type Transcription Factor ZINC FINGER OF ARABIDOPSIS THALIANA6 Modulates Biotic and Abiotic Stress Responses by Activating Salicylic Acid-Related Genes and C-REPEAT-BINDING FACTOR Genes in Arabidopsis. Plant Physiol. 2014, 165, 1367-1379. [CrossRef] [PubMed]

44. Sakamoto, H.; Maruyama, K.; Sakuma, Y.; Meshi, T.; Iwabuchi, M.; Shinozaki, K.; Yamaguchi-Shinozaki, K. Arabidopsis Cys2/His2-type zinc-finger proteins function as transcription repressors under drought, cold, and high-salinity stress conditions. Plant Physiol. 2004, 136, 2734-2746. [CrossRef] [PubMed]

45. Park, S.; Lee, C.M.; Doherty, C.J.; Gilmour, S.J.; Kim, Y.; Thomashow, M.F. Regulation of the Arabidopsis CBF regulon by a complex low-temperature regulatory network. Plant J. 2015, 82, 193-207. [CrossRef]

46. Rossel, J.B.; Wilson, P.B.; Hussain, D.; Woo, N.S.; Gordon, M.J.; Mewett, O.P.; Howell, K.A.; Whelan, J.; Kazan, K.; Pogson, B.J. Systemic and intracellular responses to photooxidative stress in Arabidopsis. Plant Cell 2007, 19, 4091-4110. [CrossRef] [PubMed]

47. Honda, C.; Moriya, S. Anthocyanin Biosynthesis in Apple Fruit. Hortic. J. 2018, 87, 305-314. [CrossRef]

48. Iida, A.; Kazuoka, T.; Torikai, S.; Kikuchi, H.; Oeda, K. A zinc finger protein RHL41 mediates the light acclimatization response in Arabidopsis. Plant J. 2000, 24, 191-203. [CrossRef]

49. Takatsuji, H.; Mori, M.; Benfey, P.N.; Ren, L.; Chua, N.H. Characterization of a zinc finger DNA-binding protein expressed specifically in Petunia petals and seedlings. EMBO J. 1992, 11, 241-249. [CrossRef]

50. Tiwari, J.K.; Munshi, A.D.; Kumar, R.; Pandey, R.N.; Arora, A.; Bhat, J.S.; Sureja, A.K. Effect of salt stress on cucumber: Na+-K+ ratio, osmolyte concentration, phenols and chlorophyll content. Acta Physiol. Plant. 2010, 32, 103-114. [CrossRef]

51. Chen, M.; Yang, Z.; Liu, J.; Zhu, T.; Wei, X.; Fan, H.; Wang, B. Adaptation Mechanism of Salt Excluders under Saline Conditions and Its Applications. Int. J. Mol. Sci. 2018, 19, 3668. [CrossRef]

52. Han, G.; Wang, M.; Yuan, F.; Sui, N.; Song, J.; Wang, B. The CCCH zinc finger protein gene AtZFP1 improves salt resistance in Arabidopsis thaliana. Plant Mol. Biol. 2014, 86, 237-253. [CrossRef]

53. Han, G.; Yuan, F.; Guo, J.; Zhang, Y.; Sui, N.; Wang, B. AtSIZ1 improves salt tolerance by maintaining ionic homeostasis and osmotic balance in Arabidopsis. Plant Sci. 2019, 285, 55-67. [CrossRef] [PubMed]

54. Zang, D.; Li, H.; Xu, H.; Zhang, W.; Zhang, Y.; Shi, X.; Wang, Y. An Arabidopsis Zinc Finger Protein Increases Abiotic Stress Tolerance by Regulating Sodium and Potassium Homeostasis, Reactive Oxygen Species Scavenging and Osmotic Potential. Front. Plant Sci. 2016, 7, 1272. [CrossRef] [PubMed]

55. Zhang, A.; Liu, D.; Hua, C.; Yan, A.; Liu, B.; Wu, M.; Liu, Y.; Huang, L.; Ali, I.; Gan, Y. The Arabidopsis Gene zinc finger protein 3(ZFP3) Is Involved in Salt Stress and Osmotic Stress Response. PLoS ONE 2016, 11, e0168367. [CrossRef]

56. Zhang, Z.; Liu, H.; Sun, C.; Ma, Q.; Bu, H.; Chong, K.; Xu, Y. A C(2)H(2) zinc-finger protein OsZFP213 interacts with OsMAPK3 to enhance salt tolerance in rice. J. Plant Physiol. 2018, 229, 100-110. [CrossRef] [PubMed]

57. Sun, Z.; Liu, R.; Guo, B.; Huang, K.; Wang, L.; Han, Y.; Li, H.; Hou, S. Ectopic expression of GmZAT4, a putative C2H2-type zinc finger protein, enhances PEG and $\mathrm{NaCl}$ stress tolerances in Arabidopsis thaliana. 3 Biotech. 2019, 9, 166. [CrossRef] [PubMed]

58. Li, Y.; Chu, Z.; Luo, J.; Zhou, Y.; Cai, Y.; Lu, Y.; Xia, J.; Kuang, H.; Ye, Z.; Ouyang, B. The C2H2 zinc-finger protein SlZF3 regulates AsA synthesis and salt tolerance by interacting with CSN5B. Plant Biotechnol. J. 2018, 16, 1201-1213. [CrossRef] [PubMed]

59. Wang, F.; Tong, W.; Zhu, H.; Kong, W.; Peng, R.; Liu, Q.; Yao, Q. A novel Cys2/His2 zinc finger protein gene from sweetpotato, IbZFP1, is involved in salt and drought tolerance in transgenic Arabidopsis. Planta 2016, 243, 783-797. [CrossRef] 
60. Kasuga, M.; Miura, S.; Shinozaki, K.; Yamaguchi-Shinozaki, K. A combination of the Arabidopsis DREB1A gene and stressinducible rd29A promoter improved drought- and low-temperature stress tolerance in tobacco by gene transfer. Plant Cell Physiol. 2004, 45, 346-350. [CrossRef]

61. Zhao, Q.; Xiang, X.; Liu, D.; Yang, A.; Wang, Y. Tobacco Transcription Factor NtbHLH123 Confers Tolerance to Cold Stress by Regulating the NtCBF Pathway and Reactive Oxygen Species Homeostasis. Front. Plant Sci. 2018, 9, 381. [CrossRef]

62. Han, G.; Lu, C.; Guo, J.; Qiao, Z.; Sui, N.; Qiu, N.; Wang, B. C2H2 Zinc Finger Proteins: Master Regulators of Abiotic Stress Responses in Plants. Front. Plant Sci. 2020, 11, 115. [CrossRef]

63. Li, C.; Wei, Z.; Liang, D.; Zhou, S.; Li, Y.; Liu, C.; Ma, F. Enhanced salt resistance in apple plants overexpressing a Malus vacuolar $\mathrm{Na}^{+} / \mathrm{H}^{+}$antiporter gene is associated with differences in stomatal behavior and photosynthesis. Plant Physiol. Biochem. 2013, 70, 164-173. [CrossRef] [PubMed]

64. Yang, Y.Y.; Zheng, P.F.; Ren, Y.R.; Yao, Y.X.; You, C.X.; Wang, X.F.; Hao, Y.J. Apple MdSAT1 encodes a bHLHm1 transcription factor involved in salinity and drought responses. Planta 2021, 253, 46. [CrossRef] [PubMed]

65. Kelley, L.A.; Mezulis, S.; Yates, C.M.; Wass, M.N.; Sternberg, M.J. The Phyre2 web portal for protein modeling, prediction and analysis. Nat. Protoc. 2015, 10, 845-858. [CrossRef] [PubMed]

66. Kumar, S.; Stecher, G.; Li, M.; Knyaz, C.; Tamura, K. MEGA X: Molecular Evolutionary Genetics Analysis across Computing Platforms. Mol. Biol. Evol. 2018, 35, 1547-1549. [CrossRef]

67. Rombauts, S.; Déhais, P.; Van Montagu, M.; Rouzé, P. PlantCARE, a plant cis-acting regulatory element database. Nucleic Acids Res. 1999, 27, 295-296. [CrossRef]

68. Clough, S.J.; Bent, A.F. Floral dip: A simplified method for Agrobacterium-mediated transformation of Arabidopsis thaliana Plant J. 1998, 16, 735-743. [CrossRef]

69. An, J.P.; Yao, J.F.; Xu, R.R.; You, C.X.; Wang, X.F.; Hao, Y.J. Apple bZIP transcription factor MdbZIP44 regulates abscisic acid-promoted anthocyanin accumulation. Plant Cell Environ. 2018, 41, 2678-2692. [CrossRef]

70. Yang, Y.Y.; Ren, Y.R.; Zheng, P.F.; Zhao, L.L.; Hao, Y.J. Cloning and functional identification of a strigolactone receptor gene MdD14 in apple. Plant Cell Tissue Organ Cult. 2019, 140, 197-208. [CrossRef]

71. Lee, H.S.; Wicker, L. Anthocyanin Pigments in the Skin of Lychee Fruit. J. Food Sci. 2010, 56, 466-468. [CrossRef]

72. An, J.P.; Wang, X.F.; Zhang, X.W.; Xu, H.F.; Bi, S.Q.; You, C.X.; Hao, Y.J. An apple MYB transcription factor regulates cold tolerance and anthocyanin accumulation and undergoes MIEL1-mediated degradation. Plant Biotechnol. J. 2020, 18, 337-353. [CrossRef]

73. Hu, W.; Huang, C.; Deng, X.; Zhou, S.; Chen, L.; Li, Y.; Wang, C.; Ma, Z.; Yuan, Q.; Wang, Y.; et al. TaASR1, a transcription factor gene in wheat, confers drought stress tolerance in transgenic tobacco. Plant Cell Environ. 2013, 36, 1449-1464. [CrossRef]

74. Ma, Q.J.; Sun, M.H.; Lu, J.; Liu, Y.J.; You, C.X.; Hao, Y.J. An apple CIPK protein kinase targets a novel residue of AREB transcription factor for ABA-dependent phosphorylation. Plant Cell Environ. 2017, 40, 2207-2219. [CrossRef]

75. Hu, D.G.; Ma, Q.J.; Sun, C.H.; Sun, M.H.; You, C.X.; Hao, Y.J. Overexpression of MdSOS2L1, a CIPK protein kinase, increases the antioxidant metabolites to enhance salt tolerance in apple and tomato. Physiol. Plant 2016, 156, 201-214. [CrossRef]

76. Zheng, P.F.; Wang, X.; Yang, Y.Y.; You, C.X.; Zhang, Z.L.; Hao, Y.J. Identification of Phytochrome-Interacting Factor Family Members and Functional Analysis of MdPIF4 in Malus domestica. Int. J. Mol. Sci. 2020, 21, 7350. [CrossRef] 